\title{
The state and prospects of preservation of some rare and relic species Lycopodiophyta at southern megaslope of the Ukrainian Carpathians (Transcarpathia)
}

\author{
LUBOV MyHAILIVNA FELBABA-KLUSHINA \\ KATERYNA ANATOLIIVNA VOTKALCHUK
}

FELBABA-Klushina L.M., VotKalchuK K.A. (2015). The state and prospects of preservation of some rare and relic species Lycopodiophyta at southern megaslope of the Ukrainian Carpathians (Transcarpathia). Chornomors' $k$. bot. z., 11 (2): 138-145. doi:10.14255/2308-9628/15.112/1.

The results of researches are represented for three species of divisio Lycopodiophyta (Diphasiastrum issleri (Rouy) Holub, Lycopodiella inundata (L.) Holub), Selaginella helvetica (L.) Spring, which are rare in Ukrainian Carpathians. Detailed description is provided for the habitats and plant communities, where these species occur; the number of individuals in the populations is detected. Their sozological status is defined with the forecast of populations' development for the nearest years.

Keywords: Ukrainian Carpathians, Transcarpathia, Diphasiastrum issleri, Lycopodiella inundata, Selaginella helvetica, habitat, areal dynamics, community characteristic, sozological state

ФЕЛЬБАБА-КЛУШИНА Л.М., ВОТКАЛЬЧУК К.А. (2015). Стан та перспективи збереження деяких рідкісних реліктових видів Lycopodiophyta на південному мегасхилі Українських Карпат (Закарпаття). Чорноморськ. бот. ж., 11 (2): 138145. doi:10.14255/2308-9628/15.112/1.

Представлені результати досліджень трьох видів відділу Lycopodiophyta (Diphasiastrum issleri (Rouy) Holub, Lycopodiella inundata (L.) Holub), Selaginella helvetica (L.) Spring, які є рідкісними в Українських Карпатах. Наведені детальні описи місцезростань та угруповань, у яких ці види трапляються, а також вивчена чисельність особин у популяціях. Визначено їх созологічний статус та зроблено прогноз розвитку популяцій у найближчі роки .

\begin{abstract}
Ключові слова: Украӥнські Карпати, Закарпаття, Diphasiastrum issleri, Lycopodiella inundata, Selaginella helvetica, місиезростання, динаміка ареалу, характеристика угруповання, созологічний статус

ФЕЛЬБАБА-КЛУШИНА Л.М., ВОТКАЛЬЧУК К.А. (2015). Состояние и перспектива охраны некоторых редких реликтовых видов Lycopodiophyta на южном мегасклоне Украинских Карпат (Закарпатье). Черноморск. бот. ж., 11 (2): 138145. doi:10.14255/2308-9628/15.112/1.

Представлены результаты исследований трех видов отдела Lycopodiophyta (Diphasiastrum issleri (Rouy) Holub, Lycopodiella inundata (L.) Holub), Selaginella helvetica (L.) Spring, которые являются редкими в Украинских Карпатах. Приведенные подробные описания местопроизростаний и сообществ, в которых эти виды встречаются, а также изучена численность особей в популяциях. Определен их созологичний статус и сделан прогноз развития популяций в ближайшие годы.
\end{abstract}

Ключевые слова: Украинские Kapnambl, Закарпатье, Diphasiastrum issleri, Lycopodiella inundata, Selaginella helvetica, местопроизростания, динамика ареала, характеристика сообщества, созологический статус

(C) L. M. Felbaba-Klushina, K. A. Votkalchuk

Чорноморськ. бот. ж., 11 (2): 138-145 
There are 12 species of divisio Lycopodiophyta [MOSYAKIN, FEDORONCHUK, 1999; EKOFLORA..., 2000] in Ukrainian flora. 9 species occur in Ukrainian Carpathians as well as on their southern megaslope, i.e. on Transcarpathian territory: Diphasiastrum alpinum (L.) Holub,. Diphasiastrum complanatum (L.), Diphasiastrum issleri (Rouy) Holub, Lycopodiella inundata (L.) Holub, Lycopodium annotinum L., Huperzia selago (L.) Bernh. ex Schrank et Mart., Selaginella helvetica (L.) Spring, Selaginella selaginoides (L.), P. Beauv.ex Mart. et Schrank, Lycopodium clavatum L. [FODOR, 1974; VYZNACHNYK..., 1977; OPREDELITEL..., 1999]. All these species, except Lycopodium clavatum, are included into the Red Book of Ukraine (2009). Our publication is dedicated to three rare species the growth of which had not been proved by herbarium specimens over 30 years (Diphasiastrum issleri, Lycopodiella inundata) and one species was supposed to be extinct (Selaginella helvetica). We succeed to prove the habitat of all these three species and start monitoring researches of their populations' development.

\section{Materials and Methods}

The researches had been held during 2006-2014 on the southern megaslope of Ukrainian Carpathians.

In order to clarify the expansion of researched species in Ukrainian Carpathians we worked up the herbarium collections from M.G. Kholodny Institute of Botany of NASU (KW), Institute of Ecology of the Carpathians (LWKS), Uzhgorod National University (UU), Y. Fedkovych Chernivtsi National University (CHER).

The names of the plants are cited S.L. Mosyakin, M.M. Fedoronchuk [MosYAKIN, FEDORONCHUK, 1999]. Geobotanical descriptions were done using classic methodic with the usage of the scale of projective covering J. Brown-Blanke.

\section{The results and their discussioins}

Lycopodiella inundata is holarctic circumpolar species and its areal embraces South America, Middle and Atlantic Europe, Scandinavian countries, Far East, Western and Eastern Siberia, the Caucasus [MEUSEL, JÄGER, WEINERT, 1965]. It is well-known in all Carpathian regions except Hungary [TASENKEVICH, 1998]. Inside its areal the species grows on the peat marshes, marshy meadows and wet sands. In Carpathians it grows mainly on the peat marshes in plant communities of classes Scheuchzerio-Caricetea nigrae (Nordh. 1937) R. Tx. 1937 of union Rhynchosporion albae Koch 1926 [COLDEA, 1997; HAJEK, HABEROVA, 2001].

Lycopodiella inundata is one of the rarest species of marshes flora in Ukrainian Carpathians which is included to the Red List of Ukraine under the category of rare [CHERVONA..., 2009], to the Red List of Transcarpathian region as extinct [KRICHFALUSHIJ, BUDNIKOV, MYHAL, 1999] and to the Carpathian List of Endangered Species as endangered [TASENKEVICH, 2003].

According to the herbarium data the species had been found in four floristic regions of Ukrainian Carpathians: in the Vyhorlat-Hutyn mountain range and in the Horhans (Southern megaslopes of Ukrainian Carpathians, Transcarpathian region) as well as in the ChyvchynGrynyava Mountains (Chernivtsi region) and in Precarpathians (Ivano-Frankivsk region), which is situated on the North-Eastern megaslopes of Ukrainian Carpathians (fig. 1).

The species is well-known by location on the Vyhorlat-Hutyn mountain range from the lake Synye (Mukachiv distr., environs of Synyak village), with the area of 3,0 ha. It has nature protection status hydrological natural memorial from 1984 [PRYRODJ-ZAPOVIDNYI..., 2011]. The data about the species growth on this territory is represented by Popovych S.Y. and Andriyenko T.L. [POPOVYCH, ANDRIENKO, 1998], which is proved by herbarium sample (Popovych, 25.05.1980 KW). During further years the growth of this species on this territory had not been proved [MYHAL, 2006]. It was resulted in missing data about the state of the population during last 30 years. In summer 2012 we proved again the habitat of the species on 


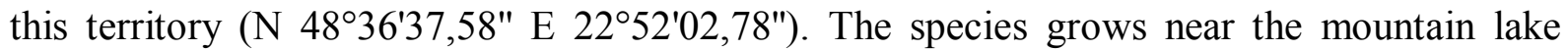
surrounded by beech-hornbeam forests on the height of $650 \mathrm{~m}$ a.s.l. The lake is on its final stage of growth and active forming of marshes phytocoenosis that is why a water surface is represented only by separate small water reservoirs with the area up to $2 \mathrm{~m}^{2}$ and depth up to 30-40 sm. Lycopodiella inundata grows in the first layer of community with projective covering 1-2\% among mosses with the domination of Sphagnum capillifolium (Ehrh.) Hedw. (30\%). Less projective covering have Aulacomnium palustre (Hedw.) Schwägr. (10\%), Polytrichum strictum Brid. (7-10\%), Sphagnum palustre L. (5\%), Sphagnum magellanicum Brid. (5\%), Calliergon stramineum (Brid.) Kindb(5\%), Bryum pseudotriqueter (Hedw.) G. Gaertn (4\%). The second layer is sparse and it is represented mainly by Carex echinata Murr. (3\%), Drosera rotundifolia L. (1-2\%), Carex nigra (+), Trientalis europaea L. $(+)$. The third layer is also sparse, not closed, with such representatives as Rubus caesius L.(1$3 \%)$, Solanum dulcamara L. (1\%), Doronicum austriacum Jacq. (+), Gentiana asclepiadea L. $(+)$. The highest fourth layer is formed by Phragmites australis (Cav.) Trin. ex Steud. (7$10 \%$ ) and separate individuals of Betula pendula Roth, Frangula alnus Mill., Picea abies (L.) Karst., Populus tremula L. Population Lycopodiella inundata is scanty, it is compounded by 21 individuals and it is in danger of extinction because the lake's overgrowing with weeds becomes more active during last year's due to increased drought duration resulted by climate warming and breakdown of hydrological regime in the basin of Tysa River.

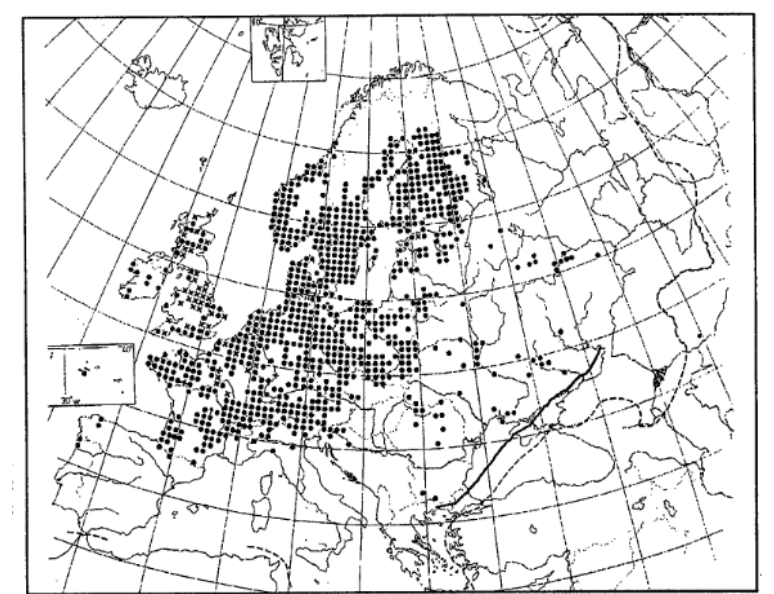

A

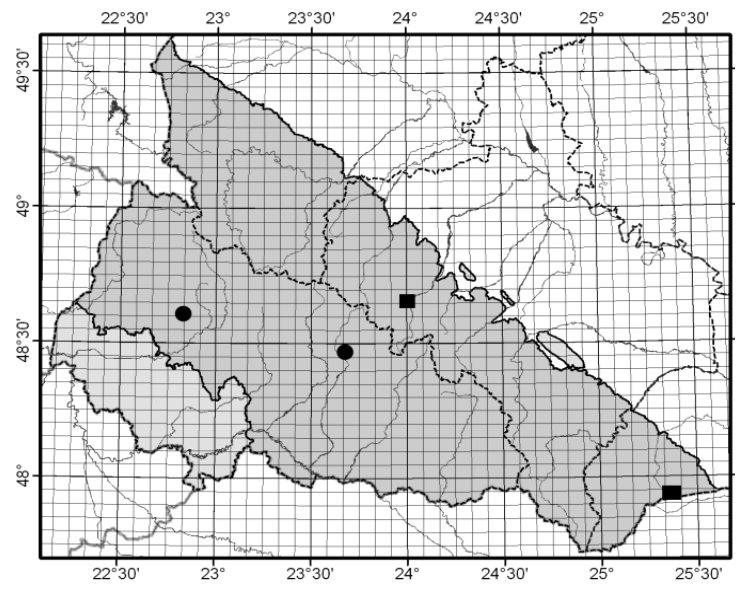

B

Fig. 1. Areal Lycopodiella inundata in Europe (A) (ATLAS..., 1972 [14]) and location in Ukrainian Carpathians (B): $\square$ - based on herbarium samples and literature data, $\bigcirc$ - herbarium samples and literature data are proved by own collections.

The species is well-known in the Horhans. It grows in oligotrophic marshes Glukhanya situated on the height of $650 \mathrm{~m}$ a.s.1 with the area 24 ha (Myzhyrsky distr., environs of Nehrovec village). The territory is the part of National Nature Park «Synevyr» from 1999 [PRYRODJ-ZAPOVIDNYI..., 2011]. Herbarium specimens were gathered by different collectors in 1963-1979 pp. (UU, KW). Lycopodiella inundata was detected by us in this location in 2009 in small water hollows surrounded by sphagnum mosses (Sphagnum capillifolium (25\%), S. magellanicum (3\%), S. papillosum (+), Polytrichum strictum (5\%) and Rynchospora alba (10 \%), Carex limosa (2\%). The geographical coordinates - N $48^{\circ} 28^{\prime} 45,04^{\prime \prime} \mathrm{E} 23^{\circ} 38^{\prime} 10,57^{\prime \prime}$. The data of previous researchers inform that in 60 -th years of $20^{\text {th }}$ century the species was one of the dominants on this marsh in community Rhynchospora alba - Lycopodiella inundata, which was also formed in water hollows [BRADIS, ANDRIENKO, LYHOBABINA, 1969]. Separate individuals Lycopodiella inundata sometimes occur even now on the whole area of the marsh which is also dries up with increasing of projective cover Molinia caerulea [FELBABA-KLUSHINA, 2010]. 
So, the transformation of oligotrophic and mesotrophic mosses, where Lycopodiella inundata is located, into peat meadows and shrubby groups results into extinction of the species from the researched territory. That's why the species should be considered as extincting in Transcarpathian territory.

Diphasiastrum issleri (Rouy) Holub is rare European species (D. alpinum $\times$ D. tristachyum) [CHERVONA..., 2009], which occurs in Central Europe, south of Northern Europe (fig. 2) [MEUSEL, JÄGER, WEINERT, 1965].

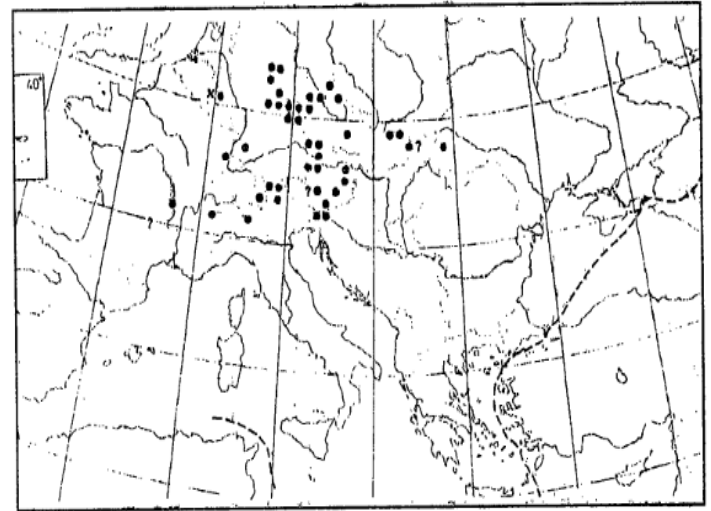

A

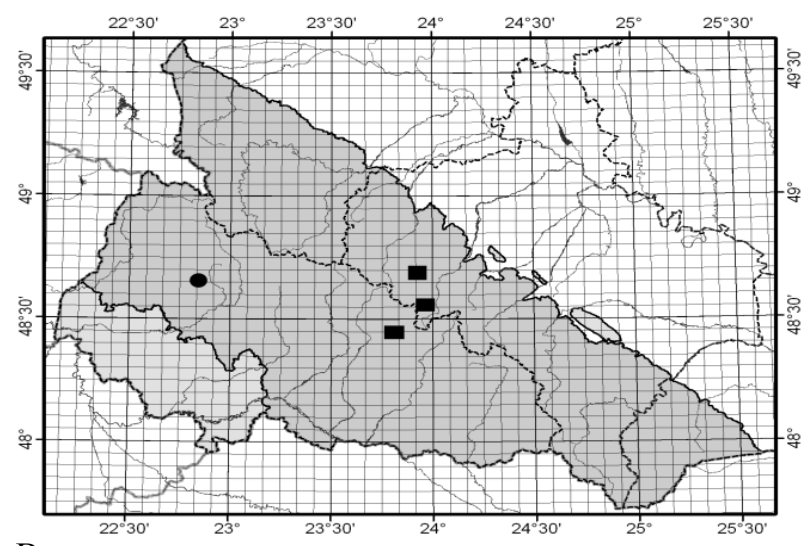

B

Fig. 2. Areal Diphasiastrum issleri in Europe (A) [ILLUSTRIRTE..., 1984] and location in Ukrainian Carpathians (B): $\square$ - based on herbarium specimens and literature data; $\bigcirc$ - a new habitat of the species.

The species is spread in three locations in the Horhans. So, A. Pacyna informed about the location of this species on the mount Yayko Ilemske (Ivano-Frankivsk region) and mount Popadya (Transcarpathian region) [PACYNA, 1972]. There are data about herbarium specimens from mount Strymba in the researches of V.V. Protopopova. The specimens had been gathered by F. Hryn' in 1948 (herbarium of AS USSR) and they are the intermediate form between $D$. alpinum and D. issleri [PROTOPOPOVA, 1974].

In 2012 we detected Diphasiastrum issleri on the slopes of mount Dunauka environs of Olenevo village, Svalyavskyy district (the Vyhorlat-Hutyn mountain range) on the hight of $680 \mathrm{~m}$ a.s.1. (N 48 $\left.39^{\prime} 07,07^{\prime \prime} \mathrm{E} 22^{\circ} 52^{\prime} 03,25^{\prime \prime}\right)$. The species grows in the plantation of Sorbus domestica L. (60\%), Betula pendula Roth $(20 \%)$ and Acer platanoides L. $(+)$. The crown closure is around $70 \%$. The population Diphasiastrum issleri has 4 individuals growing on the area of $300 \mathrm{~m}^{2}$ together with Rubus caesius L.(15\%), Senecio fuchsia C.C. (+), Majanthemum bifolium (L.) F.W.Schmidt (+), Gymnocarpium dryopteris (L.) Newm. (2$3 \%$ ), Huperzia selago (L.) Bernh. ex Schrank \& C.Mart. (5\%), Lycopodium annotinum L. (5\%), Polygonatum odoratum (Mill.) Druce (1\%), P. verticillatum (L.) All. (1\%), Oxalis acetosella L. (+), Gentiana asclepiadea L. (3\%), Dryopteris carthusiana (Vill.) H.P.Fuchs $(10 \%)$.

The population is not endangered and we consider it as rare due to its infrequency.

Selaginella helvetica - is characterized by disjunctive areal that embraces Central and North-Eastern Europe, Asia Minor, the Caucasus, Eastern Siberia, the Far East [MeUSEL, JÄGER, WEINERT, 1965; FLORA..., 1974]. In Carpathians Selaginella helvetica occurs on the territory of Slovakia, Ukraine and Romania [TASENKEVICH, 1998]. The Vyhorlat-Hutyn mountain range (Volcanic Carpathians) is the only reliable habitat of the species in Ukraine. Here the species was found in the environs of Veryatsya village of Vynogradivskyy district and it is proved by number of herbarium specimens gathered by different collectors (fig. 3) [CHERVONA..., 2009]. In 1931 the species was detected and gathered by I. Bucek in Verytsya village on the height of $350 \mathrm{~m}$ a.s.1. [DOMIN, 1931]. A. Margitay informs about the collected 
specimens of Selaginella helvetica on this territory [MARGITTAI, 1938]. K.N. Ihoshyna [IHOSHYNA, 1955] provides the data about the growth of the species near the foot of the mountain ridge on the height of $170 \mathrm{~m}$. There are no specimens of this species in the worked up herbarium collections of Ukraine (KW, LWKS, UU).

There are data about the growth of the species in Uzhgorod, v. Korolevo, on Chorna Hora as well as on the mountain ridge Svydovets [OPREDELITEL..., 1999; FODOR, 1974; FLORA..., 1974]. It is clear that such kind of information about species habitat require firm proof but we failed to find this species across mentioned settlements due to inaccurate literature data.

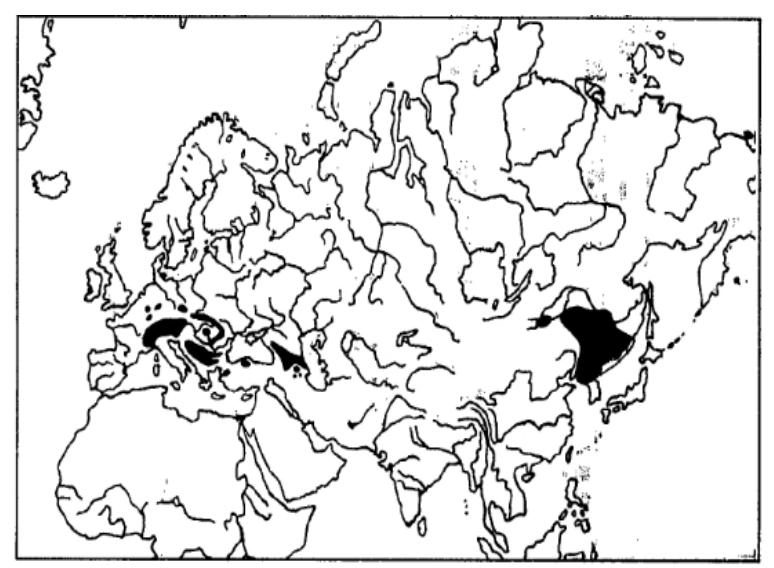

A

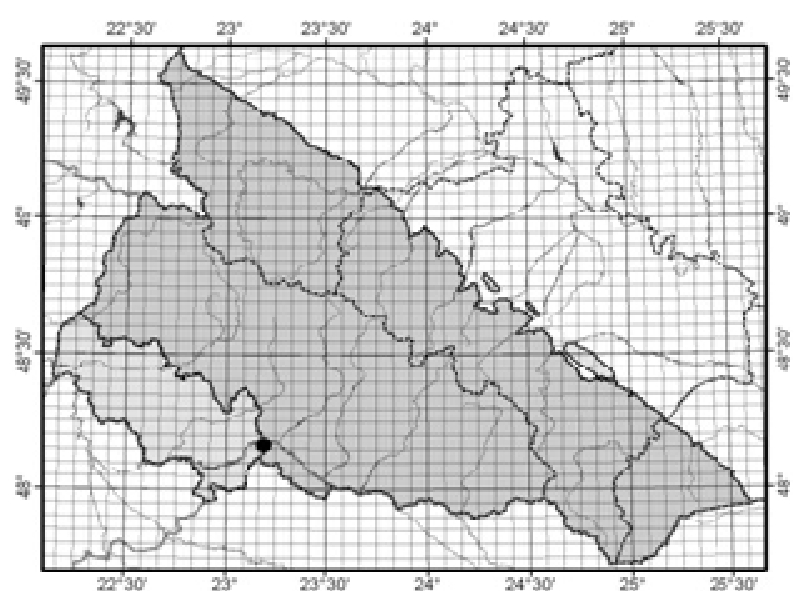

B

Fig. 3. Areal Selaginella helvetica in Eurasia (A) [MEUSEL, JÄGER, WEINERT, 1965] and location in Ukrainian Carpathians (B):

There were no herbarium proofs of Selaginella helvetica habitat more than 50 years and its presence in the flora of Ukraine and Ukrainian Carpathians was doubtful.

As was already mentioned, Selaginella helvetica is usually spread out over the mountain regions. In neighbour Slovakia the species occurs on the height diapason of 130-180 $\mathrm{m}$ a.s.l. in wet grass thickets, on shaded rocks but near Bratislava it grows on meadows, pastures, in gardens and forests with the plantations of Robinia pseudoacacia L. [FLÓRA..., 1966]. In Romania the species occurs on the mountain rocks in subalpine and alpine climatic zone [FlORA..., 1952] the same as in the Caucasus [HROSSHEJM, 1936]. So, Selaginella helvetica has relatively wide diapason of highland habitat and spreading.

The species is included into the Red Book of Ukraine under the category of extinct [CHERVONA..., 2009], into the Red List of Transcarpathian region as endangered [KRICHFALUSHIJ, BUDNIKOV, MYHAL, 1999], and into the Carpathian List of Endangered Species as vulnerable [TASENKEVICH, 2003].

In 2013 we detected Selaginella helvetica on the slopes of the left bank of Tysa River on the height of $265 \mathrm{~m}$ a.s.1. environs of Veryatsya village of Vynogradiv district (N 48 $10^{\prime} 38,09^{\prime \prime}$ E $23^{\circ} 09^{\prime} 54,67^{\prime \prime}$ ) (fig. 3). The researched slopes are characterized by the outcrop of volcanic rocks of andesites and andesite-basalts [FODOR, 1974].

The data about phytocenotic confined of the species are very limited. Such information is absent in the scientific work of H. Ellenberg et al. [ELLENBERG at al., 1991]. It was informed that the species occurs in the plant communities of union Seslerion in ecologic characteristics of vulnerable species of vascular plants represented by V.V. Krichfalushiy and others [FODOR, 1974]. We failed to determine the syntaxonomic status of communities with Selaginella helvetica due to insufficient quantity of geobotanical descriptions. But our description can be included into according data-base after the collection of data from other regions. 
Mean slope gradient $-30^{\circ}$. Mycrorelief is hilly. The projective covering of harbage is around $80 \%$ and individual covering of Selaginella helvetica does not exceed $1 \%$. The following separate young trees are also available Pinus sylvestris L. $(+)$ and Betula pendula Roth. (+) with the height up to $3 \mathrm{~m}$. We detected in harbage Poa pratensis L. (7 \%), Festuca pseudovina Hackel ex Wiesb. (5\%), Centaurea jacea L. - (10\%), Thymus alternans Klokov (10\%), Leucanthemum vulgare Lam. (5\%), Hypochaeris glabra L. (5\%), Galium verum L. (3\%), Briza media L. (3\%), Euphorbia cyparissias L. (3\%), Pilosella officinarum F.Schultz \& Sch.Bip. (1\%), Linum catharticum L. (1 \%), as well as Aristolochia clematitis L., Agrimonia eupatoria L., Carlina vulgaris L., Achillea millefolium L., Equisetum arvense L. and Kohlrauschia prolifera (L.) Kunth. - occasionally.

So, the community is full of the species most of which are typical components of meadows. But there are also species which have no clear phytocoenotic confined and give to phytocoenos the features of synantropization.

The slope where the researched species was found is being trampled down by people and cattle. Moreover, the territory is fragmented by number of paths. Taking into account that $S$. helvetica is stress-tolerant it can maintain its positions in the community during some time. But the nearby location of andesite-stone processing plant creates the risk of possibility to create new open pit on the slope which is the only known place of location of this species in Ukrainian Carpathians. That is why we proposed to create botanic zakaznik "Veryatsya" with the area of 0,5 ha in order to protect the population Selaginella helvetica from direct negative impact of human activities and to create appropriate conditions for monitoring researches focused on the population state. So, the status of the species meets the status 'rare'.

\section{Conclusions}

Three representatives of divisio Lycopodiophyta - Lycopodiella inundata, Diphasiastrum issleri and Selaginella helvetica are very rare on the southern megaslope of Ukrainian Carpathians. They have only one or two known habitats with relict characteristics of their areal.

Selaginella helvetica is known on the whole Ukrainian territory only from the one habitat detected by us in Volcanic Carpathians and it is affected by anthropogenic factors. Due to these facts it is rare and endangered at the same time.

Diphasiastrum issleri was not found in the locations mentioned in literature sources but was detected for the first time on Volcanic ridge in the artificially created community of brushwood. This is also the only known habitat of the species in Ukrainian Carpathians. There are no direct dangers for the population in terms of human activities. It is considered by us as rare in Ukrainian Carpathians.

Lycopodiella inundata located in meso- and oligotrophic marshes is known by four locations in Ukrainian Carpathians, two of them belong to the southern megaslope of Ukrainian Carpathians. Its habitat was confirmed in both locations but a drastic reduction of population size was observed as the result of marshes transformations into types of phytocoenoses. That is why the species is endangered despite of the location on natureprotected territories.

The researches gave the possibility to start the monitoring of the populations state of rare relict species Lycopodiella inundata, Diphasiastrum issleri and Selaginella helvetica. It can significantly supplement the scientific data about the strategy of the species and their reaction on protected measures.

\section{References}

ATLAS Florae Europeae. Distribution of Vascular plants in Europe I. (1972). Eds. J. Jalas, J. Suominen. Helsinki. $121 \mathrm{p}$.

Bradis E.M., Andrienko T.L., Lyhobabina E.P. (1969). Ukr. botan. zhurn., 26 (1): 29-34. [БРАДіс Є.M., АНДРІєНКо Т.Л., ЛихОБАБІнА Є.П. (1969). Оліготрофні болота Закарпатської області. Укр.ботан. журн., 26 (1): 29-34] 
Chervona knyha Ukrainy. Roslynnyi svit (2009). pid zah. Red. Ya. P. Diduha. K.: Hlobalkonsaltynh. 912 p. [ЧЕРВОНА книга України. Рослинний світ (2009). під заг. ред. Я. П. Дідуха. К.: Глобалконсалтинг. 912 с.]

ColdeA Gh. (1997). Classe Scheuchzerio-Caricetea nagrae. Les associations végétales de Romanie. T.1.Presses Universitaires de Cluj. P. 109-134.

Domin K. (1931).Schedae ad floram cechoslowenicam exsiccatam. Acta bot. Bohem. Cent., III (X): 3-79.

EкOFloRA Ukrainy (2000). К.: Fitisociocentr. Т.1. 283 р. [ЕКОФЛОРА України (2000). відпов. ред. Я.П. Дідух. Київ: Фітосоціоцентр. Т.1. 284 с.]

Ellenberg at all. Zeigerwerte von Pflanzen in Mitteleuropa (1991). Scripta Geobotanica, Gottingen: Verlag Erich Golize KG. V. 18. 175 s.

FelbabA-Klushina L.M. (2010). Roslynnyi pokryv bolit i vodoim verkhivia baseinu r. Tysa (Ukrainski Karpaty) ta fliuvialna konceptsiia yoho okhorony. Uzhhorod: Lyra. 192 p. [ФЕЛЬБАБАКлукшинА Л.М. (2010). Рослинний покрив боліт і водойм верхів'я басейну р. Тиса (Українські Карпати) та флювіальна концепція його охорони. Ужгород: Ліра. 192 с.]

FLORA Evropeiskoi chasti SSSR (1974). Leningrad: Izd-vo «Nauka». 1. 403 р. [ФлоРА европейской части СССР (1974). Под ред. А.А. Федорова. Ленинград: Изд-во «Наука». 1. 403 с.]

Flora Republicii Populare Române (1952). Red. T. Sâvulescu. Editora Academiei Republicii Populare Române. $656 \mathrm{~s}$.

FLÓRA Slovenska (1966). Red. Dr. Ján Futák. Vydavatelstvo Slovenskej Akadémie vied. 1. 345 c.

Fodor S.S. (1974). Flora Zakarpatia. Lviv: Vysha shkola. 207 p. [Фодор C.C. (1974). Флора Закарпаття. Львів: Вища школа. 207 с.]

Hajek M., Haberova I. (2001). Scheuchzerio-Caricetea fuscae. Rastlinné spoločenstvá Slovenska. 3. Vegetácia mokradí. Bratislava: Veda. S. 185-275.

Hrosshejм A.A. (1936). Analyz flory Kavkaza. Baku. 269 p. [Гроссгейм А.А. (1936). Анализ флоры Кавказа. Баку. 269 с.]

Ihoshinav K.N. (1955). Dopolneniia k flore Zakarpatskoi oblasti USSR. Botan. materyaly gerbariia Bot. in-ta im. V.L. Komarova AN SSSR. 17. P. 461-517. [ИгошинА К.Н. (1955). Дополнения к флоре Закарпатской области УССР. Ботан. материалы гербария Бот. ин-та им. В. Л. Комарова АН CCCP. 17. C. 461-517]

Illustrirte Flora von mitteleuropa: Pteridophyta, Spermatophyta. Dd. I. Teil 1 (1984). G. Hegi, Hrsg. Hans, J. Conert. Berlin; Hamburg: Parey, Teilw. im Verl. Hanser, Munchen. $310 \mathrm{~s}$.

Krichfalushij V.V., Budnikov H.B., Myhal A.V. (1999). Chervonyi spysok Zakarpattia: vydy Roslyn ta roslynni uhrupovannia, scho znahodiatsia pid zahrozoiy znyknennia. Uzhhorod: Zakarpattya, Patent. 196 р. [КРІЧФАЛУшІй В.В., БУднІкОВ Г.Б., МиГАЛь А.В. (1999). Червоний список Закарпаття: види рослин та рослинні угруповання, що знаходяться під загрозою зникнення. Ужгород: Закарпаття, Патент. 196 с.]

MargitTai A. (1938). Az Északkeleti-Kárpátok néhány érdekes növénye. Botanikai Közlemények, 35 (1-2): 58 63.

Meusel H., JÄGer E., Weinert E. (1965). Vergleichende Chorologie der Zentraleuropäischen Flora. Jena: Fischer Verl,. Bd. 583 s.

Mosyakin S.L., Fedoronchuk M.M. (1999). Vascular plants of Ukraine. A nomenclatural checklist. Kyiv. $345 \mathrm{p}$.

MYHAL A.V. (2006). Roslynnyi pokryv olihotrofnykh sfahnovyh bolit Zakarpatskoi oblasti. Bolotni ekosystemy rehionu Skhidnyh Karpat v mezhah Ukrainy. Uzhhorod: Lira. P. 38-44. [МигАЛЬ А.В. (2006). Рослинний покрив оліготрофних сфагнових боліт Закарпатської області. Болотні екосистеми регіону Східних Карпат в межах України. Ужгород: Ліра. С. 38-44]

OpREDELITEL vysshih rastenii Ukrainy (1999). [Dobrochaeva D.N., Kotov M.I., Procudin Yu.N. i dr.]. Kiev: Nauk. Dymka. 207 p. [ОПРЕДЕЛитеЛь высших растений Украины (1999). [Доброчаева Д.Н., Котов М.И., Прокудин Ю.Н. и др.]. Киев: Наук. думка. 548 с.]

Pacyna A. (1972). Polskie gatunki rodzaju Diphasium Presl i ich rozmieszczenie w kraju. Fragm. Flor. Geobot., 18 (3-4). P. 309-341.

POPOVYCH S.Yu., ANDRIENKO T.L. (1998). Ridkisni vydy flory hirskykh bolit Ukrainskykh Karpat ta stan ikh ohorony. Zberezh. florist. riznom. Karpat. rehiony: mat-ly nauk.-prakt. konf., 1-4 zhovtnya 1998 r., Synevir. Uzhhorod. Р. 120-122. [Попович С.Ю., Андрієнко Т.Л. (1998). Рідкісні види флори гірських боліт Українських Карпат та стан їх охорони. Збереж. флорист. різном. Карпат. регіону: мат-ли наук.-практ. конф., 1-4 жовтня 1998 р., Синевир. Ужгород. С. 120122] 
Protopopova V.V. (1974). Ukr. botan. zhurn., 31 (6): 690-694. [Протопопова В.В. (1974). Нові для України види роду Diphasium C. Presl. Укр. ботан. журн., 31 (6): 690-694]

PRYRoda Zakarpatskoji oblasti (1981). pid red. K.I. Herenchuka Lviv: Vysha shkola. 156 p. [ПРиРодА Закарпатської області (1981). / під ред. К.І. Геренчука. Львів: Вища школа. 156 с.]

PrYRodJ-ZAPOVIDNYI fond Zakarpatskoji oblasti (2011). pid zah. red. S.S. Popa. Uzhhorod: Karpaty. 256 p. [ПриРодно-ЗАПовІдний фонд Закарпатської області (2011). під. заг. ред.. С.С.Попа. Ужгород: Карпати. 256 с.]

TASEnKevich L.O. (1998). Pryrodna flora Karpat. Spysok vydiv sudynnyh roslin. Lviv: Derzhavnyj pryrodoznavchij muzej NAN Ukrainy, X111. 610 p. [ТАСєНКЕВИч Л.О. (1998). Природна флора Карпат. Список видів судинних рослин. Львів: Державний природознавчий музей НАН України, Х111. 610 с.]

TASENKEVICH L. (2003). Vaskular plants . Carpathian List of Endangered Species. Z. J. Witkowski, W. Kril, W. Solarz (eds.). Vienna-Krakow: WWF and Institute of Nature Conservation, Polish Academy of Sciences. P. 6-19.

VYZNACHNYK roslyn Ukrajinskyh Karpat (1977). [Vidp. Red. V.I. Chopyk]. K.: Nauk. Dumka. 435 p. [ВизнАчник рослин Українських Карпат (1977). [відп. ред. В.І. Чопик]. К.: Наук. думка. 435 c.]

Рекомендує до друку

Отримано 13.01.2015

\section{Р.П. Мельник}

Aдpeca авторів:

Л.М. Фельбаба-Клушина

К.А. Воткальчук

Ужсгородський національний університет

вул. Волочина, 32

Ужггород 88000, Україна

e-mail:kunik35@yandex.ru

e-mail:katya_votkalchuk@mail.ru
Authors' address:

L.M. Felbaba-Klushina

K.A. Votkalchuk

Uzghorod National University

32, Voloshyn str.

Uzghorod 88000, Ukraine

e-mail:kunik35@yandex.ru

e-mail: katya_votkalchuk@mail.ru 